\title{
The Impact of Corruption and Rent-Seeking Behavior upon Economic Wealth in the European Union from a Public Choice Approach
}

\author{
Gheorghița Dincă *(D), Marius Sorin Dincă (D), Camelia Negri and Mihaela Bărbuță
}

Citation: Dincă, G.; Dincă, M.S.; Negri, C.; Bărbuță, M. The Impact of Corruption and Rent-Seeking Behavior upon Economic Wealth in the European Union from a Public Choice Approach. Sustainability 2021, 13, 6870. https://doi.org/10.3390/ su13126870

Academic Editor: Mihaela Onofrei

Received: 15 May 2021

Accepted: 10 June 2021

Published: 17 June 2021

Publisher's Note: MDPI stays neutral with regard to jurisdictional claims in published maps and institutional affiliations.

Copyright: (c) 2021 by the authors. Licensee MDPI, Basel, Switzerland. This article is an open access article distributed under the terms and conditions of the Creative Commons Attribution (CC BY) license (https:// creativecommons.org/licenses/by/ $4.0 /)$.
Department of Finance and Accounting, Transilvania University of Braşov, 500036 Braşov, Romania; marius.dinca@unitbv.ro (M.S.D.); camelia.negri@student.unitbv.ro (C.N.); mihaela.barbuta@unitbv.ro (M.B.) * Correspondence: gheorghita.dinca@unitbv.ro; Tel.: +40-723-604-854

\begin{abstract}
The current paper evaluates the impact of corruption and rent-seeking behaviors upon economic wealth in the European Union states using a public choice approach. The period of study is 2000 to 2019. To measure this impact, the present study uses a regression with variables reflecting governance quality and considered relevant, from a public choice approach, to corruption and rentseeking. The main results of this study show a negative relationship between the level of corruption and economic wealth for all analyzed countries, especially for the ones that compose the new member states group. For all the EU member states, the variables capturing governance quality seem to have a positive impact on economic wealth. The higher levels of governance performance, synonymous with lower levels of rent-seeking, personal interest, and political pressures on state administrations, contribute to economic wealth, as public choice theory emphasizes. There is a need for reform and an increase in the efficiency of public institutions, especially in new member states.
\end{abstract}

Keywords: corruption; rent-seeking; economic wealth; public choice

\section{Introduction}

The impact of corruption and rent-seeking upon society has been debated in numerous papers over the years, yet these issues remain a topic of interest and analysis as they concern the allocation of public financial resources and taxpayers' interests.

Corruption and rent-seeking phenomena are found in most economies, no matter whether they are emerging, developing, or developed. However, there are specificities concerning their extension and the way they affect economic wealth, the functioning of markets, and the development and welfare of nations.

Corruption is a complex, multifaceted phenomenon, which interferes with other phenomena or behaviors, such as tax evasion, rent-seeking, and bribery, which, most of the time, generate negative effects across the evolution of the society.

From a public choice perspective, corruption and rent-seeking are state system failures; results of institutional weaknesses, lack of transparency, and inefficient bureaucracy; and a manifestation of the purely personal interests of elected/appointed officials.

Public choice theory concerns various aspects of state system failures and its inefficiency; the real degree of state intervention into the economy; increasing income inequality; the concept of the state made subject by different interest groups; the efficiency of the voting system as basis for democracy; and the fight against bureaucracy, corruption, and the rent-seeking phenomenon.

The innovative aspect of the public choice doctrine resides in its daring to analyze political institutions and implicitly governmental action through an economic approach, as such, differentiating itself from traditional political conceptions. The most important participants in the political game, the politicians, are mainly preoccupied with winning elections, whilst the main participants in the market game, the firms, have profit as their 
main objective. There is no plausible reason for which people, acting in view of maximizing their own market utility, would act differently when dealing with public goods.

From the perspective of public choice theory, corruption and rent-seeking behavior are specific to the state sector: to bureaucrats and politicians who use their public offices and functions to maximize their own utility.

The object of this study is to offer an empirical assessment of the effects that rentseeking behavior and corruption have upon the economic wealth of European Union countries through variables expressing governance quality.

The aim of the paper is to identify and develop an appropriate panel data regression to evaluate the impact that corruption and rent-seeking behavior exert upon economic wealth, accounting for the quality of governance.

The research tasks are:

- To present the concepts of corruption and rent-seeking;

- To underline the effects of these phenomena upon economic growth, as reflected in reference literature;

- To analyze the relationship between economic wealth, corruption, and rentseeking activities;

- To develop and improve an appropriate statistical model to express the impact that corruption and rent-seeking behavior exert upon economic wealth.

The research question is as follows:

- Do corruption and rent-seeking have a negative effect upon economic wealth in European countries? At the same time, this study looks to answer why corruption manifests differently in different countries and what the possible causes are for amplifying this phenomenon.

The current paper measures the impact of corruption and of rent-seeking behavior upon the economic wealth in European Union (EU) countries from a public choice perspective. The member countries are divided into two subsamples of new member states (NMS) and old member states (OMS), as the countries that recently joined the EU have younger democracies and are mostly registered as developing countries. For example, Romania is considered a developing country according to the International Monetary Fund (IMF) and the Organisation for Economic Cooperation and Development (OECD), whilst according to the World Bank (WB) and to purchasing power parity per capita, it is a developed country.

The analysis is continued for all member states as part of one sample to identify whether the results differ from previous ones with the countries separated into two subsamples. To ensure a better evaluation of the impact these phenomena have upon economic wealth from a public choice perspective, a panel-type regression was applied, comprising all the EU countries for the 2000-2019 period, which included variables expressing the quality of governance, such as voice and accountability, government effectiveness, rule of law, and control of corruption. These latter were considered instrumental in exposing the weaknesses of the public system and of its representative institutions, the lack of quality of public services, and the lack of freedom from political influences and interest groups.

The paper contributes to reference literature with its original and complex approach to the impact of corruption and rent-seeking phenomena upon economic wealth, with the quality of governance perspective bringing extra added value to the analysis.

The originality of this paper resides in re-examining the contemporary issues of corruption and rent-seeking, as well as the effects they have upon economic wealth at the level of all EU member countries through a public choice approach. To achieve this, an econometric model inspired by Thach et al. was developed and improved [1]. Starting from the acknowledgment of the roles that corruption and rent-seeking behavior have in all sectors of the economic, social, and political activities of any given state, the present study looks to identify and evaluate how governance quality influences the allocation process of public resources and, implicitly, economic wealth. To highlight and compare these aspects, the analysis was performed separately for the two samples of NMS and OMS, as well as for 
the entire set of EU countries. As such, this study completes the research of the reference literature, highlighting the quality of governance.

The research paper is organized as follows: the introduction defines the purpose of the research; the second section reflects a brief literature review; the third section presents the methods used to evaluate the impact of corruption and rent-seeking behavior upon economic wealth from a public choice approach; section four presents empirical results; and section five discusses and presents the main conclusions.

\section{Literature Review}

Public choice theory was created more than 50 years ago and has evolved constantly since. It has gained ever more acknowledgment, influencing both the scientific community and general public attitudes and way of thinking. A simple comparison with 1950s prevailing public opinions reveals a much more critical stand of the academic community and of the general public toward politicians and politics, a more prudent approach of political actions' motivations, and a less naïve position in appreciating that political and bureaucratical solutions are the most appropriate to social problems [2]. This theory starts from the premise that all individuals act to maximize their utility on the market, hence, analyzing individuals' social option [3].

The theory focuses on the behavior of the public sector's decision-makers, which, similarly to private individuals, have as primary interest the maximization of their individual utility, which motivates them to act for their own private good. In the opinion of the neo-liberals, proponents of this theory, common good, or the so-called common interest, is considered more of a utopia. People learn fast to use with an interest any right or power they acquire or they can assume. Public money and public freedom will be quickly identified as sources of wealth and domination for the ones who have them [4].

Corruption undermines citizens' confidence in the general well-being and destroys the legitimacy of the political system [5]. Aidt [6] considers that corruption has two main components: the "helping hand" type of corruption, which appears when the power to decide is transferred to a group of malevolent or poorly prepared group of people, and the "grabbing hand" type of corruption, which originates from politicians approving inefficient policies and measures for their own advantages, the latter encompassing the previously mentioned aspect that individuals cannot place common good ahead of their own interests.

In the public choice approach, corruption is associated with public administration's non-transparent processes and procedures, burdened by excessive bureaucracy, which does not include citizens in the decision-making process. Moreover, the corruption and power abuse phenomena in view of achieving individual interests is seriously impacting the economic life of all market participants, as well as economic wealth and growth.

The debates concerning the definition and the way in which corruption affects the economy and society continue and incite researchers, even now, to explore different approaches to this phenomenon. Corruption is considered the phenomenon of disobeying the rules and current laws by individuals, who follow, on their own or by cooperation with third parties, the promotion of their own benefit [7].

Political limitations of traditional development models can be corrected by incorporating public choice ideas regarding corruption mitigation programs and the improvement of institutional quality [8].

Corruption includes the theft of public resources by vested officials; promoting nepotism and favoring personal relations in various circumstances; embezzlement of public funds; fiscal evasion, along with any other abusive employment of public positions; and in addition to non-completing various social attributes, the abatement from public role to promote personal agenda; as well as facilitating economic or interest transactions, taking bribes, and accepting monetary or non-monetary benefits [9].

It is quite obvious that corruption is present in the sphere of political actors, as well as at the level of individual taxpayers. In the case of population, corruption manifests via fiscal evasion, breaking field legislation, or not paying taxes, as well as operating economic 
activities in an illegal framework and not observing or ignoring current legislation. Nevertheless, the public choice theory is concerned mainly with irregularities found in the governmental apparatus, analyzing political behavior, and looking for recommendations meant to mitigate political opportunism, corruption, and rent-seeking phenomena.

The majority of reference literature papers revealed that corruption has a strong negative impact upon economic growth and upon the efficiency of economic activity [10-14]. Corruption negatively impacts private investments, employment rate, and income per capita [15]. An auto-regressive distributed lag (ARDL) model was applied to study the long-term relationship between corruption and economic development for Tunisia, revealing the same negative effect of the former [16]. The results showed that, in the long term, a 1\% increase in corruption led to a $1 \%$ decrease in gross domestic product (GDP) per capita.

The relationship between institutional quality, corruption level, and economic growth, using the partial least squares (PLS) method was studied for a sample of 120 countries [17]. The results showed that institutional quality, as well as corruption, have a negative influence upon economic growth in analyzed countries. Additionally, the impact of corruption upon economic growth in Indonesian provinces was measured, considering a corruption threshold with a non-linear approach [18]. The results were interpreted according to the levels of corruption registered by different provinces in relation to this threshold, concluding that whenever corruption is situated above the established threshold, it generates bad effects for the economy.

Corruption is closely connected to other negative phenomena, such as fiscal evasion, as found by several authors $[13,19]$. In addition, corruption and fiscal evasion are complementary in low-income countries, as evidenced by other researchers [20,21].

There are studies revealing that, in countries with a mature democracy system, corruption does not have a significant effect upon economic growth, whereas non-democratic countries register a significant economic prejudice because of this phenomenon [22]. Moreover, states with established democratic institutions and a high level of economic wealth create instruments and procedures to control the political class and punish corrupt politicians [23]. On the other hand, weak institutions play an important role in the pro-cyclicality of rent-seeking [24].

Other researchers consider corruption as a tax paid by individuals or different entities to bureaucrats to fend off existing regulations, offering them a certain type of freedom, which finally leads to an increase in economic efficiency [25].

Houston [26] accepted that corruption generates negative effects as well, however maintained that long-term positive externalities may appear in countries that do not rigorously respect citizens' personal and economic rights. The author exemplifies this with bribery paid in case of infrastructure civil works that otherwise would not have been realized.

Swaleheen and Stansel [27] have obtained different results concerning the relationship between corruption and economic growth, using economic freedom as an explanatory variable. Their research was realized for a 60 states data panel, revealing that, for countries with a low level of economic freedom, corruption has negative effects, whereas in the countries with a high level of economic freedom, the impact of corruption upon economic growth is a positive one.

Corruption and rent-seeking phenomena were also analyzed from the indebtedness degree perspective, showing that countries with a high corruption level also display a high level of public debt [28]. The authors maintain that local and central governments' fight against corruption will generate better fiscal compliance levels. On the other hand, citizens appreciate the efforts made by governments in the fight against corruption, indictments, and convictions for public corruption cases leading to a population's increased trust in government and state institutions [29].

An interesting corruption approach is presented by Capasso and Santoro [30], who developed a model to express two categories of corruption, respectively, one active at the public officials level and a passive one, at the private agents level, who are looking for illicit 
favors. Their results show how active corruption significantly negatively affects companies' productivity compared to passive corruption. The authors also mention that distortion of public functional expenditures has a long-term negative impact upon the education and health sectors. As such, corruption threatens social and economic stability and can reduce the potential for economic growth.

Countries with significant rent-seeking activities, such as corruption, weak, and permissive juridical systems, will experience negative economic effects with reduced innovative activities and rates of economic growth [31].

The market economies generate significant differences in income and wealth. The less wealthy segments of the population require redistributive policies, yet they are even more justified to ask for these when inequalities originate from corruption and rent-seeking activities [32].

Sketched by Gordon Tullock [33] and subsequently renamed by Krueger [34], the rent-seeking phenomenon represents the attempts of certain interest groups to obtain private privileged benefits from the government [6,35]. Iqbal and Daly present several definitions of this phenomenon, added to its universally accepted definition [36]. Their paper is reminiscent of Tullock [33], which presents rent-seeking as the activity of receiving income without any productivity associated, and Fisher [37], which claims rent-seeking implies an inefficient allocation of limited public resources toward interest groups' activities. Moreover, the two authors add to these approaches, suggesting that rent-seeking activity implies the captive state concept, as well as any other attempt of public officials, politicians, and even individuals, of making profits from the functioning of the state apparatus. Other authors present rent-seeking behavior as the attempts of some individuals or groups (such as certain politicians, public officials, or trade unions) of imposing adoption of some fiscal-budgetary or regulatory measures to a country's government, allowing them to obtain financial gains or other material advantages at the expense of the general mass of taxpayers, of consumers, or of other types of groups with which the beneficiaries can be in economic competition $[2,38]$. At the same time, the taxpayers financing these services do not practically benefit from them and they cannot avoid paying those respective taxes, since they are too many to easily express their interests publicly [39].

Stigler [40] criticizes bureaucracy that becomes captive to certain interest groups and creates rules and regulations in favor of these groups. For the enormous benefits that can be gained from the political process, the interest groups are willing to spend big amounts of money for lobbying activity, which brings them special privileges, an activity called rent-seeking [41].

The corruption phenomenon has been, hence, considered a manifestation of rentseeking activities [31,34]. On the other hand, in his work regarding this phenomenon, Aidt [6] recalls that even if they are similar socio-economic manifestations, the corruption concept does not imply, and it is not always overlapped with the rent-seeking phenomenon and vice versa.

Lambsdorff [7] states corruption is different from rent-seeking by referring to the law and transparency and citing Jain [42]: "corruption is considered the obscure part of the competition, whilst rent-seeking activity is taking place under the scrutiny of virtually all economic environment's participants, moreover, the person appointed in a public office exerting his position in view of creating a legal basis for undertaking activities for his own benefit. No matter how those phenomena are viewed, it is widely accepted that they cause imbalances with significant externalities upon economic activity, implying the unproductive use of state resources or their embezzlement, thereby causing losses for the society".

Another important topic highlighted by public choice school's representatives is political and administrative bureaucracy, which refers mainly to the ever-increasing size of public institutions and the efficiency of governmental administration, as well as to the old administrative procedures and the high hierarchy structure from within public institutions [43]. Butler [41] signals the increase of the state apparatus because of public em- 
ployees' personal interests. The author completes his paper with a reference to Downs' [44] study, which, inside an economic analysis of bureaucracy, studied bureaucrat behavior. The bureaucrat, based on convenience and personal interest, looks for workplace security and stability within an important department, which has a significant budget allocated, accepting changes only as far as the advantages obtained outweigh the efforts of adapting to the respective changes.

The negative effects of bureaucracy are translated into inefficiency, considering that public employees' performances are difficult to monitor and their duties are sometimes vague. This inefficiency leads to other negative effects of bureaucracy, such as increased taxation to support the growing administrative establishment, a more difficult interaction with the state apparatus due to numerous layers of public administration and numerous documents needed, lack of digitalization, corruption, and lack of transparency toward the population, as well as discouragement of economic activities [43]. The public choice ideology looks to reduce both bureaucracy and the state intervention into the economy, mainly by using market infrastructure and de-politicization of government institutions [45]

All these aspects of the political scene evidenced by public choice theory, namely, rentseeking, corruption, and bureaucracy, have significant effects upon a state sector's efficiency and represent an impediment for economic growth [46]. The proponents of public choice theory highlight the rational character of politicians, bureaucrats, and public employees, identical to the private sector's agents with regard to maximizing personal utility at the expense of collective interest. These scholars point out the waste of budgetary resources, their inefficient allocation, and the lack of real competition inside the public sector.

A strong democratic environment favors increased measures against corruption, underlying the importance of regulating institutions meant to control these phenomena. In this way, the discrepancy is explained between stable bureaucracy countries, where corruption control is proven to have a positive impact upon economic growth, and countries with a young bureaucracy, where the corruption phenomenon is more present, mainly due to the vicious circle made up of political representatives and the legislation promoted by themselves [36].

The main recommendation of public choice policies refers to the state system and to the public financial policies' reform to generate an increase of economic efficiency and equity inside public institutions, as well as reforms meant to restrict the ever-growing social expenditures, the number of non-performing public employees, the reduction of meritocracy and corruption, as well the de-politicization and freeing of state from the interest groups.

The proponents of public choice theory state the important role of the state in the economy as that of securing a transparent and efficient legislative framework and protecting individuals' economic freedom. The main challenge brought about by this economic school of thinking to the political sphere concerns the way decisions are taken, considering the real democracy principles, which implies a model of decision-making meant to ensure a better satisfaction of citizens' needs and preferences.

\section{Materials and Methods}

The main goal of this research paper is to determine and emphasize the impact of corruption and rent-seeking activities upon economic wealth through panel data regression models. Considering the empirical studies performed so far, and following the theoretical framework for this specific area, this paper is based on the econometric model developed by Thach, Duong, and Oanh [1]. Furthermore, the model used in the research incorporates variables reflecting the quality of governance, such as voice and accountability, government effectiveness, rule of law and control of corruption, relevant from a public choice point of view on corruption and rent-seeking $[14,47,48]$.

Aiming to demonstrate the empirical relationship between corruption and economic wealth, the panels were built for the 2000-2019 period, as this was the most recent period for which statistical institutions published complete data, with some exceptions for a few 
isolated cases. Thus, the analysis was performed on all member states of the European Union, including the United Kingdom, over a period of 20 years. Furthermore, the analysis was conducted on three samples considering the moment in time when each country joined the European Union structure (with 2004 as the main reference). Considering this, the considered samples are:

1. Total sample, including all 28 member states of the EU.

2. OMS sample, including member states that joined the EU before 2004 (15): Austria, Belgium, Denmark, Finland, France, Germany, Greece, Ireland, Italy, Luxembourg, the Netherlands, Portugal, Spain, Sweden, and the United Kingdom.

3. NMS sample, including member states that joined the EU after 2004 (13): Bulgaria, Croatia, Cyprus, Czech Republic, Estonia, Hungary, Latvia, Lithuania, Malta, Poland, Romania, Slovakia, and Slovenia.

The variables used in the model, based on the one developed by Thach, Duong, and Oanh [1], are presented in Table 1 below.

Table 1. The variables.

\begin{tabular}{|c|c|c|c|c|}
\hline Dependent Variable & Unit & Abbreviation & & Source \\
\hline $\begin{array}{l}\text { Real gross domestic } \\
\text { product per capita }\end{array}$ & Euro/capita & gdpcap & & Eurostat \\
\hline Independent variables & Unit & Abbreviation & Expected influence & Source \\
\hline $\begin{array}{l}\text { Corruption perception } \\
\text { index (rescaled) }\end{array}$ & Score $(0-10)$ & cpi_rescaled & - & Transparency Int \\
\hline Democracy index & Score $(0-10)$ & democ & + & $\begin{array}{l}\text { V-Dem Institute- } \\
\text { Department of Political } \\
\text { Science, University } \\
\text { of Gothenburg }\end{array}$ \\
\hline $\begin{array}{l}\text { Economic freedom } \\
\text { summary index }\end{array}$ & Score $(0-10)$ & ecfreed & + & $\begin{array}{l}\text { Fraser Institute-Economic } \\
\text { freedom of the world (EFW) }\end{array}$ \\
\hline Total fixed assets & $\%$ of GDP & investm & + & Eurostat \\
\hline $\begin{array}{l}\text { Crude rate of total } \\
\text { population change }\end{array}$ & $\begin{array}{l}\text { Population's change during } \\
\text { the year to the average } \\
\text { population (per } 1000 \text { persons) }\end{array}$ & popchange & + & Eurostat \\
\hline Trade openness & $\%$ of GDP & trade & + & World Bank \\
\hline Education attainment & $\begin{array}{c}\text { Tertiary education attainment } \\
\% \text { of total population } \\
\text { between } 25-64\end{array}$ & ed & + & Eurostat \\
\hline $\begin{array}{l}\text { Government } \\
\text { expenditure }\end{array}$ & $\%$ of GDP & govexp & + & Eurostat \\
\hline $\begin{array}{c}\text { Voice and } \\
\text { accountability }\end{array}$ & Score $(-2.5 ; 2.5)$ & voice & + & $\begin{array}{l}\text { World Bank Governance } \\
\text { Indicators Database }\end{array}$ \\
\hline $\begin{array}{l}\text { Government } \\
\text { effectiveness }\end{array}$ & Score $(-2.5 ; 2.5)$ & goveff & + & $\begin{array}{c}\text { World Bank Governance } \\
\text { Indicators Database }\end{array}$ \\
\hline Rule of law & Score $(-2.5 ; 2.5)$ & rlaw & + & $\begin{array}{l}\text { World Bank Governance } \\
\text { Indicators Database }\end{array}$ \\
\hline Control of corruption & Score $(-2.5 ; 2.5)$ & contrcorr & + & $\begin{array}{l}\text { World Bank Governance } \\
\text { Indicators Database }\end{array}$ \\
\hline
\end{tabular}

Data source: authors' processing.

Thus, for the considered analysis, the regression equation reads:

gdpcap $_{i t}=\alpha+\beta_{1}$ cpi_rescaled $_{i t}+\beta_{2}$ democ $_{i t}+\beta_{3}$ ecfreed $_{i t}+\beta_{4}$ investm $_{i t}+\beta_{5}$ popchange $_{i t}+\beta_{6}$ trade $_{i t}+\beta_{7}$ ed $_{i t}+\beta_{8}$ govexp $_{i t}$ $+\beta_{9}$ voice $_{i t}+\beta_{10}$ goveff $_{i t}+\beta_{11}$ rlaw $_{i t}+\beta_{12}$ contrcorr $_{i t}+\mu_{i}+\varepsilon_{i t}$ 
where the dependent variable is represented by $g d p c a p_{i t}$, followed by independent variables cpi_rescaled $_{i t}$, democ $_{i t}$, ecfreed $_{i t}$, investm $_{i t}$, popchange $_{i t}$, trade $_{i t}$, ed $_{i t}$, govexp $_{i t}$, voice $_{i t}$, goveff $_{i t}$, rlaw $_{i t}$, contrcorr $_{i t}$, and $\mu_{i}$, which captures the constant effect and particularity of each European Union state $i=1,2 \ldots 28$, with $\varepsilon_{i t}$ as the error term, correlated with the independent variables.

The corruption index (CPI) is the main independent variable, summarizing the levels of corruption for each state of the EU28, and the most used variable to measure corruption in reference literature. According to transparency international methodology, CPI varies from 0 to 10 points for each state, where a higher score suggests a less corrupt country. To facilitate interpretation of the output, the corruption index was rescaled, subtracting each country's score from the maximum value of 10 points [47]. As such, the rescaled version of CPI revealed higher levels of corruption in countries with higher scores. Thus, a higher corruption score is expected to manifest a negative impact on economic wealth, measured in this study through GDP per capita variable, due to the theft of public resources and pursuit of personal interest to the detriment of the public one, as emphasized by public choice theory. Democracy index, as well as economic freedom index are another two important independent variables used in the model built by Thach et al. [1,49-51]. For this research, the average of the five dimensions of democracy developed by V-Dem Institute from the University of Gothenburg was considered. This variable analyzes quality of democracy through five integrative dimensions of the phenomenon, namely, electoral democracy, liberal democracy, participatory democracy, deliberative democracy, and egalitarian democracy. The average index takes values in the range of $(0 ; 1)$, with the upper limit of the range corresponding to a higher quality democracy level. A more democratic environment leads to more competitive and expanding economic activity, whose added value will contribute to economic wealth. Alongside economic freedom, together, they summarize the quality of democracy and freedom of each European Union member state, emphasizing the government's capacity to ensure transparency and freedom of individuals. However, these variables consider economic freedom as a whole.

For a more detailed image of the impact each area of democracy has on economic wealth and to better underline the public choice theory hypotheses, four more indicators of governance quality were considered, namely, voice and accountability, government effectiveness, rule of law, and control of corruption. The voice and accountability variable was used to emphasize media freedom, as well as freedom of individual speech, as part of civil liberties [48]. Furthermore, for the rule of law indicator, Groșanu et al. [52] give a plurality of meanings, such as the extent to which citizens and social actors comply with the law, especially with regard to property rights, law enforcement, and the courts, as well as the quality of these provisions, while also considering the risk of crime and violence in the respective state. Control of corruption, as stated in the World Bank methodology, captures the forms of corruption at the state apparatus level, the extent to which public office positions are exerted to maximize politicians' self-interest, as well as the extent to which public institutions are held captive by groups of interest. Furthermore, the government effectiveness variable was considered, which points to the quality of public services and policies, together with the commitment and actions taken to achieve the objectives mentioned in the governance plan. All these variables take values in the range of $(-2.5 ;+2.5)$, with a higher score expressing a higher government performance, expected to exert a positive influence on economic wealth.

Other independent variables considered in this research are investment level, measured by total fixed capital formation as a percentage into GDP, population growth, and the level of import and exports (as \% of GDP), with total government expenditures (as \% of GDP) and population's level of studies (the percentage of the population aged 25-64, who have completed a higher education cycle) being classified as control variables. Following the theory of economic wealth's determinants, all these variables are expected to manifest a positive impact on the GDP per capita [12]. 
The influences of all these variables on the dependent variable after running the model are presented in the section of empirical results. Table 2 and Appendix A summarize main descriptive characteristics of the variables used, from a statistical point of view.

Table 2. Descriptive statistics for total EU28 sample.

\begin{tabular}{cccccc}
\hline Variable & Obs & Mean & Std. Dev. & Min & Max \\
\hline gdpcap & 558 & $24,383.010$ & $15,875.340$ & 3010 & 84,420 \\
cpi_rescaled & 553 & 3.668 & 1.780 & 0.000 & 7.400 \\
democ & 560 & 0.743 & 0.085 & 0.356 & 0.855 \\
ecfreed & 532 & 7.606 & 0.407 & 5.550 & 8.500 \\
investm & 560 & 22.128 & 4.116 & 10.100 & 45.600 \\
popchange & 560 & 2.573 & 8.583 & -35.000 & 41.700 \\
trade & 560 & 116.948 & 64.958 & 45.419 & 408.362 \\
ed & 554 & 26.575 & 9.249 & 5.400 & 47.300 \\
govexp & 560 & 44.634 & 6.463 & 24.500 & 65.100 \\
voice & 532 & 1.121 & 0.340 & 0.220 & 1.801 \\
goveff & 532 & 1.136 & 0.604 & -0.373 & 2.354 \\
rlaw & 532 & 1.121 & 0.615 & -0.260 & 2.100 \\
contrcorr & 532 & 1.034 & 0.792 & -0.491 & 2.470 \\
\hline Data & & & &
\end{tabular}

Data source: authors' processing.

Standard deviation, which illustrates the extent to which the values of each variable deviate from their average, is essential to this analysis. The most notable standard deviation is the one of gross domestic product, at 15,875.34 euro/capita, emphasizing the heterogeneity of analyzed EU countries in terms of economic development. The country with the highest positive abatement of GDP/capita from the EU28 average of 24,383.01 Euro/capita is Luxembourg, (which, in 2007, registered the maximum value of the considered data set of 84,420 Euro/capita), followed by Ireland, Denmark, Sweden, and the Netherlands. At the opposite pole, we find Bulgaria, with a minimum value of 3010 Euro/capita in 2000, followed by other East European countries, such as Romania, Latvia, and Croatia.

Another important standard deviation is emphasized in the case of the trade openness variable (with 64.95756). The European countries least engaged in the global trading system are France, Greece, the United Kingdom, Spain, and Romania, while countries such as Ireland, Luxembourg, Malta, and Slovenia have significant imports and exports compared to their gross domestic product. In the case of Italy, the sum of exports and imports represented only about $45.41 \%$ of the national GDP in 2009 , compared with Luxembourg, whose trade activities were approximately four times higher than the national GDP in 2015.

The least significant standard deviation is in the democracy index (with 0.0845). On average, for the 20 years under analysis, in the European Union, the average democracy index was 0.743 . The country with the highest democracy index was Denmark (holding the highest level of the sample, respectively, of 0.855 reached in 2012), followed by Germany and Sweden, whereas at the opposite end, we saw Romania, Poland, Bulgaria, and Hungary, (which reached the lowest level of democracy in 2019 with a value of 0.356 , raising questions about the quality of Hungarian freedom and democracy).

Economic freedom index, voice and accountability, government effectiveness, rule of law, and control of corruption also display reduced levels of standard deviation, the EU's 28 countries being more homogeneous in this case. For all these variables, the highest levels were recorded in Finland, Denmark, and Sweden, whereas on the opposite side, the lowest levels were displayed by Bulgaria, Croatia, Greece, and Romania.

The rescaled corruption perception index varies from the minimum of 0 to the maximum of 7.4; the higher the score, the higher the corruption perceived. The best-performing countries in view of transparency international were northern countries, such as Denmark, Finland (which in 2000 was considered free of corruption with a score of 0), Sweden, the Netherlands, and Luxembourg. On the other hand, countries with young democracies, with a tough period of transition to the market economy, reported high levels of corruption 
and rent-seeking. Among the latter, we found countries such as Bulgaria, Romania, Croatia, Greece, Poland, and Slovakia. The highest level of corruption was reported in Romania in 2003, a country that, even today, still records the highest corruption levels from the whole EU block. Moreover, it is specified that corruption and nepotism phenomena are the main obstacles faced by Romanian companies, in the perception of $85 \%$ and $82 \%$ of the companies, respectively, significantly above the EU averages of $37 \%$ and $38 \%$, respectively, suffocating and impeding economic development [53] (p. 55).

In Figures 1 and 2, GDP/capita and CPI rescaled scatterplot for OMS and NMS, respectively, are represented.

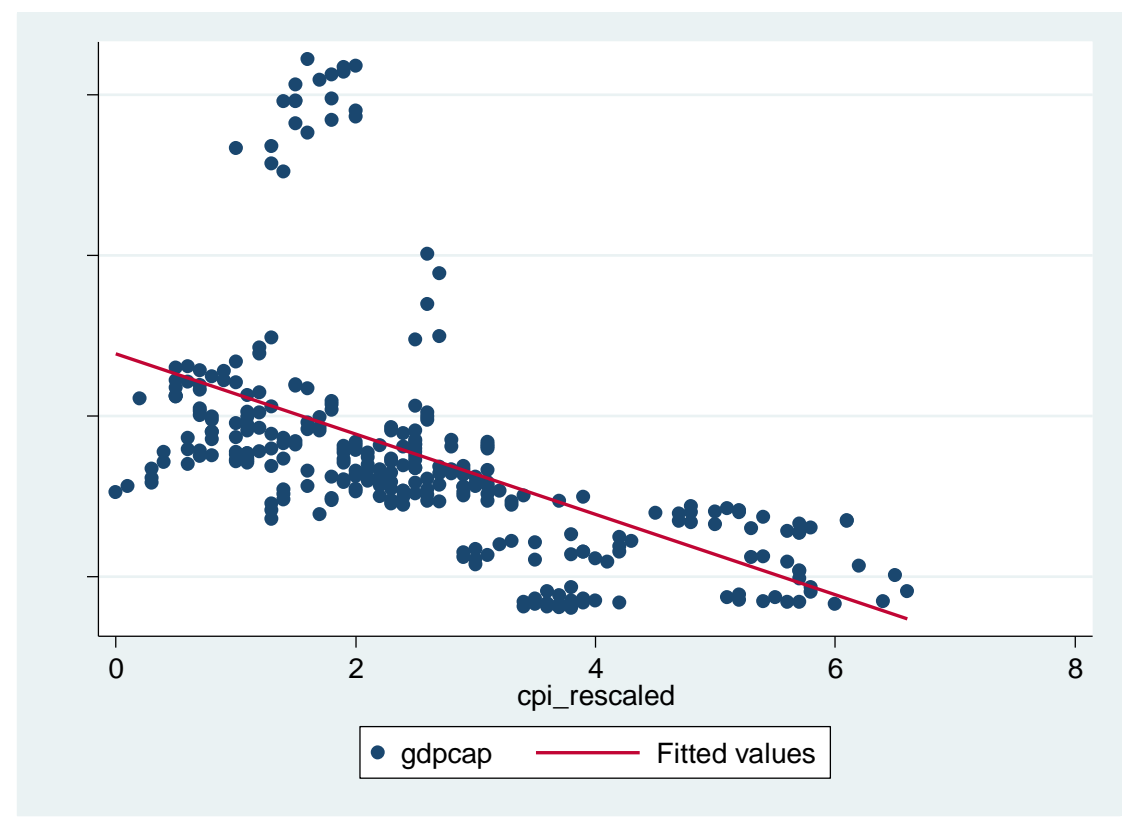

Figure 1. GDP/capita (euro/capita) and CPI rescaled scatterplot for the OMS sample. Source: authors' processing using Stata software.

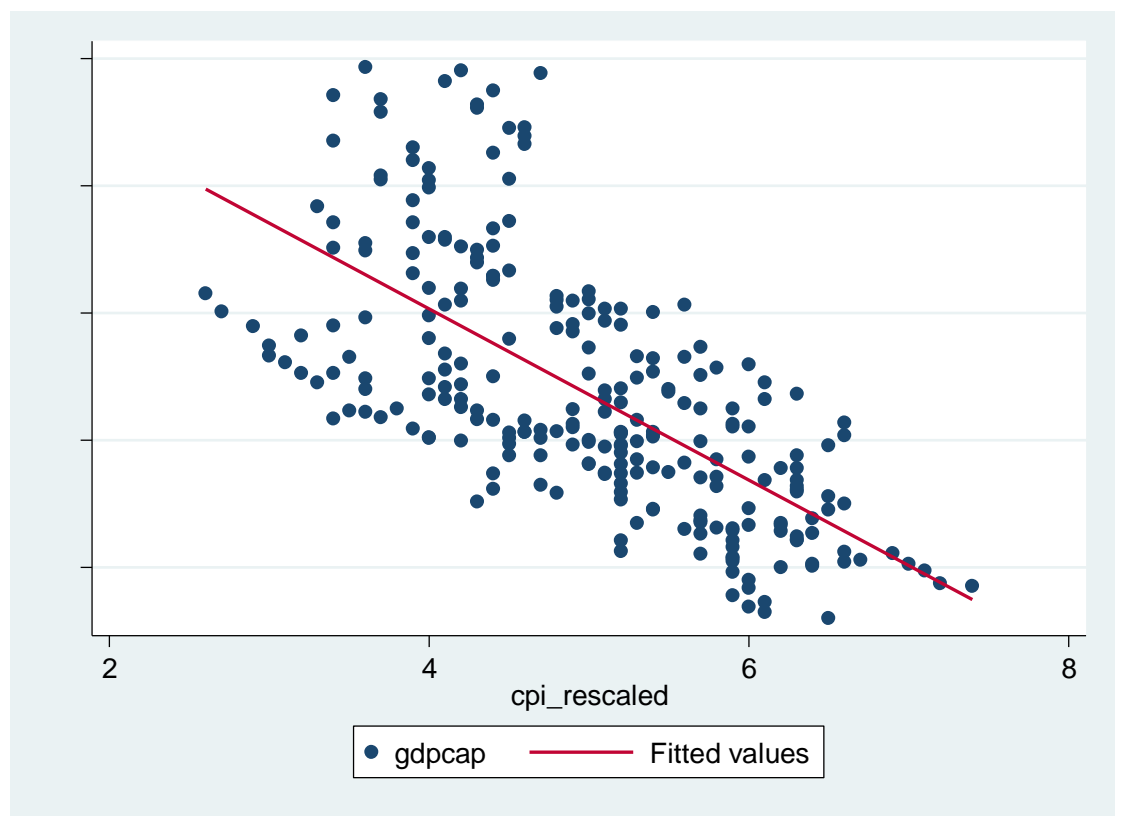

Figure 2. GDP/capita (euro/capita) and CPI rescaled scatterplot for the NMS sample. Source: authors' processing using Stata software. 
On average, in the 2000-2019 period, the percentage of the population aged between 25 and 64 who completed a higher education cycle in the European Union was of 26.57\%. The European countries that had, on average, the lowest level of the population with higher education in the 2000-2019 period were Romania, followed by Italy and Malta, whereas at the opposite pole, we find Finland, Ireland, Luxembourg, and the United Kingdom. The lowest value of the variable was found in the case the Malta in 2000, with only 5.4\% of people aged between 25 and 64 having higher education. Although most EU28 countries were on the rise in terms of participation in higher education during the analyzed period, Ireland was at its peak in 2019 , with $47.3 \%$ of the population over the age of 25 achieving a diploma of higher education. Furthermore, over the past 20 years, many European countries faced population declines due to both migratory and natural causes, such as Romania, Poland, Lithuania, Latvia, Hungary, Croatia, and Bulgaria, the latter reaching the highest level of population decline in 2001, when population declined with about $35 / 1000$ persons in comparison with the previous year. However, more developed EU countries, such as Luxembourg, Ireland, Malta, Spain, and Cyprus, reported a growing population during the recent years. The most sudden increase in population took place in Malta in 2019, with 41.7/1000 persons.

In the case of investment and government expenses, the standard deviations were lower than $10 \%$. In both scenarios, on average, European Union countries were relatively close to the average. The lowest level of total fixed assets reported in the European Union was in countries such as Greece, (which is also in a slight decline, reaching the lowest level of capital formation in 2019, with only of $10.1 \%$ of the GDP), Cyprus, Italy, Portugal, and the United Kingdom. On the opposite pole, with the highest level of assets as a percentage of GDP and far from the EU average of $22.13 \%$, are countries such as Czechia, Estonia, Ireland (which recorded the highest level of capital formation in the EU; 45.6\% in 2019), and Spain. The governments of Belgium, Denmark, Finland, Sweden, and France recorded the highest budget expenditures relative to GDP for most the years, whilst the highest level was recorded by Ireland in 2010, with 65.1\% of GDP. However, these exceedingly high government expenditures were not sustainable, and they decreased dramatically after that steep growth during the global economic crisis. For example, at the end of 2019, Ireland reached the lowest level of public expenditure from the entire sample, with only $24.5 \%$ of GDP, recording a lower level than Romania, Lithuania, Latvia, and Bulgaria.

Furthermore, at the same time, the descriptive analysis followed the interpretation of variables based on the two main subsamples of EU countries defined above: OMS and NMS. According to the EU accession criterion, it was found that in the case of all variables considered in the model, with the exception of total fixed assets and trade as \% into GDP, the EU veteran states displayed better values than the countries that joined the EU community after 2004. In addition, the fact that those two variables recorded higher values in the NMS countries was not necessarily relevant considering that their GDP per capita was significantly lower than that of OMS (in average 35,018.27 euro/capita in the OMS compared to 12,016.43 euro/capita in the NMS). In terms of democracy, economic freedom, and variables that reflect governance quality, the OMS recorded significantly higher scores than NMS, which was expected due to their older democracies and liberal history. Hence, the corruption perception was also lower, on average, in OMS (2.55) compared to NMS (4.99). As anticipated, old member states recorded higher percentages of government expenses, as well as higher percentages of the population aged between 25 and 64 who completed a higher education cycle, in comparison with the new member states.

Targeted policy-makers, by using the output of this study as a reference and the incentive needed, should promote the right measures to support the creation of sustainable development for all parties involved, especially for the population they represent and also for themselves. These measures can help stakeholders to avoid the public policies that create difficulties for their businesses and also help them find appropriate and positive solutions in the way of their development. To improve governance quality and increase 
the public sector's efficiency, economic and anti-corruption policies must aim at reforming public institutions' structure and activity.

\section{Results}

In this research paper, three main modelling techniques have been used in statistical analysis, namely, pooled ordinary least square (Pooled OLS), random effects model (REM), and fixed effects model (FEM), as the most common techniques used by previous papers in this field for this type of panel data. However, each model has its own limitations, and, considering the significance tests, it was decided to analyze the impact of corruption on economic wealth through feasible generalized least squares model (FGLS) when testing the subsamples NMS and OMS, whilst OLS with panel-corrected standard errors model (PCSE) was used in the case of the whole EU28 sample.

The analysis began with a simple OLS regression performed on the above-mentioned panel data, which contained all the 28 EU member states for the 2000-2019 period. Investigating the whole sample, while also considering the moment each country joined the European Union structure (integrated before/after 2004) and performing the BreuschPagan/Cook-Weisberg and White heteroscedasticity tests, the null hypothesis of homoscedasticity was rejected (with the p-value of 0.0000 being smaller than the 0.05 ), hence, the OLS model was found unsuited for the data type, presenting signs of heteroscedasticity. Testing the multicollinearity using the variance inflation factors (VIF), it was found that contrcorr, cpi_rescaled, rlaw, voice, and goveff had high VIF values, meaning that those variables could be estimated by the dataset's other independent variables.

Furthermore, the hypothesis was strongly sustained by performing OLS regression with country dummies and testing for the joint significance of these dummies. In conclusion, pooled OLS is not the best choice for this model in all three scenarios. Thus, the main issue with regard to pooled OLS regression is the fact that data from various units, namely, EU countries, were combined and considered similar or identical, without regard for individual differences and particularities, which in reality, could not be proven to be true [54]. Even though part of the European Union, the considered states displayed specific economic and cultural characteristics, differentiating them from each other, hence, a model controlling for these particularities should be considered. In conclusion, a panel data regression was indicated to be performed. Performing the Breusch and Pagan Lagrangian multiplier test for random effects, the results ( $p$-value $=0.0000<0.05$ ) indicated the use of REM over the pooled OLS for both total sample and OMS sample.

The REM emphasized that variation across countries was considered to be random, and the unobserved variables were assumed to be uncorrelated with the independent variable [55]. For the purpose of deciding between FEM and REM, both the Hausman test and Sargan-Hansen test to control for heteroscedasticity were performed. Both tests indicated significant results ( $p$-value $=0.0000<0.05$ ), suggesting the use of FEM over REM in all three scenarios. Furthermore, the performed Chow test also indicated that the FEM was the best-suited model considering the database sets. Summarizing all the arguments mentioned above, the FEM was more suitable considering the panel sets.

FEM assumes there is a factor within the entity (in this case EU countries) that may have an impact on dependent variables, and this needs to be controlled. The assumption of a correlation between the entity's error term and variables to be explained is centered on this characteristic of the FEM. The fixed effects model controls the effect of those times' invariant characteristics so the net effect of independent variables on the dependent variable can be evaluated properly [55]. The fixed effects model was also presented through the least squares dummy variables model (LSDV), where a dummy variable that absorbed the particular effect of each country was taken into account. By doing so, the pure effects of each independent variable on gdpcap variable were estimated while also controlling for unobserved heterogeneity across countries.

Furthermore, when performing the Breusch-Pagan LM test of independence, modified Wald test for groupwise heteroskedasticity, Wooldridge test for autocorrelation in 
panel data, as well as Pesaran's test of cross-sectional independence on FEM, the results ( $p$-value $=0.0000<0.05$ in all tests, for all samples) showed the limitations of FEM, emphasizing the presence of serial correlation, heteroscedasticity, and cross-sectional dependence in our three panels. To control for all these phenomena and obtain more reliable results, a panel-corrected standard errors regression (PCSE) for the whole sample was chosen, since the size of cross-section in this particular case (28 countries) was higher than the number of years considered. Additionally, a feasible generalized least squares (FGLS) regression was selected for OMS and NMS subsamples, where in both cases, the cross-section (15 and 13) was lower than the 20 years period considered [56,57].

To reduce disparities between variables, an option was to analyze them with their logarithmic form, as many other studies have proposed in the past, using as an example the model built by $\mathrm{Al}$ Qudah et al. [16]. However, considering the nature of the data set, including the negative changes in population, as well as the negative values encountered in the case of governance quality indicators provided by the World Bank, the data sets could be altered. The logarithmic version of this model performed well in indicating the best-suited model for the data type; however, in the case of diagnostic tests, the results were inconclusive (some of them, such as the Breusch-Pagan LM test of independence and the Pesaran test, could not be performed due to the lack of variables in this logarithmic version of the model). In this scenario, even though the logarithmic form attenuated the discrepancies and abnormal variables fluctuations, the model analyzing the nominal values of variables was best suited for the data set as it presented clear, accurate, and concise results while allowing performance and interpretation of specified diagnostic tests.

To determine whether chosen models were significant and valid, the Fisher global significance test was performed. In this case, the hypothesis that all variables' coefficients are not significantly different from 0 was rejected, showing that the set of explanatory variables included in the model significantly influenced the dependent variable gdpcap in all three scenarios for all the models performed, as $p$-value of $\mathrm{F}$ statistic in all scenarios was equal to zero. However, as pointed out above, the analysis was focused on FEM with LSDV, as well as on PCSE/FGLS models.

Table 3 shows significant variables for all models according to $p$-values.

Table 3. $p$-values showing statistical significance of the considered variables.

\begin{tabular}{|c|c|c|c|c|c|c|c|c|c|c|c|c|c|c|c|}
\hline \multicolumn{16}{|c|}{ Dependent Variable: gdpcap } \\
\hline $\begin{array}{c}\text { Independent } \\
\text { Variables }\end{array}$ & \multicolumn{3}{|c|}{ Pooled OLS } & \multicolumn{3}{|c|}{ REM } & \multicolumn{3}{|c|}{ FEM } & \multicolumn{3}{|c|}{ LSDV } & \multicolumn{3}{|c|}{ PCSE/FGLS } \\
\hline & EU28 & OMS & NMS & EU28 & OMS & NMS & EU28 & OMS & NMS & EU28 & OMS & NMS & EU28 & OMS & NMS \\
\hline cpi_rescaled & 0.010 & 0.032 & 0.248 & 0.211 & 0.478 & 0.247 & 0.270 & 0.888 & 0.059 & 0.270 & 0.888 & 0.059 & 0.001 & 0.532 & 0.000 \\
\hline democ & 0.010 & 0.000 & 0.467 & 0.580 & 0.253 & 0.466 & 0.545 & 0.163 & 0.000 & 0.545 & 0.163 & 0.000 & 0.092 & 0.023 & 0.210 \\
\hline ecfreed & 0.757 & 0.139 & 0.449 & 0.022 & 0.137 & 0.448 & 0.036 & 0.202 & 0.187 & 0.036 & 0.202 & 0.187 & 0.478 & 0.285 & 0.407 \\
\hline investm & 0.000 & 0.000 & 0.618 & 0.000 & 0.000 & 0.617 & 0.000 & 0.000 & 0.000 & 0.000 & 0.000 & 0.000 & 0.212 & 0.023 & 0.000 \\
\hline popchange & 0.000 & 0.000 & 0.000 & 0.000 & 0.136 & 0.000 & 0.000 & 0.073 & 0.000 & 0.000 & 0.073 & 0.000 & 0.000 & 0.151 & 0.000 \\
\hline trade & 0.000 & 0.000 & 0.671 & 0.000 & 0.000 & 0.671 & 0.000 & 0.000 & 0.000 & 0.000 & 0.000 & 0.000 & 0.000 & 0.000 & 0.000 \\
\hline ed & 0.496 & 0.066 & 0.002 & 0.000 & 0.000 & 0.002 & 0.000 & 0.000 & 0.000 & 0.000 & 0.000 & 0.000 & 0.222 & 0.000 & 0.000 \\
\hline govexp & 0.004 & 0.007 & 0.107 & 0.000 & 0.000 & 0.105 & 0.000 & 0.000 & 0.686 & 0.000 & 0.000 & 0.686 & 0.973 & 0.164 & 0.054 \\
\hline voice & 0.298 & 0.476 & 0.008 & 0.578 & 0.628 & 0.007 & 0.391 & 0.428 & 0.216 & 0.391 & 0.428 & 0.216 & 0.021 & 0.247 & 0.378 \\
\hline goveff & 0.002 & 0.061 & 0.000 & 0.662 & 0.715 & 0.000 & 0.465 & 0.558 & 0.044 & 0.465 & 0.558 & 0.044 & 0.350 & 0.556 & 0.003 \\
\hline rlaw & 0.050 & 0.269 & 0.000 & 0.000 & 0.027 & 0.000 & 0.000 & 0.090 & 0.000 & 0.000 & 0.090 & 0.000 & 0.103 & 0.028 & 0.028 \\
\hline contrcorr & 0.000 & 0.976 & 0.503 & 0.149 & 0.036 & 0.502 & 0.051 & 0.035 & 0.078 & 0.051 & 0.035 & 0.078 & 0.000 & 0.003 & 0.878 \\
\hline Constant & 0.838 & 0.023 & 0.044 & 0.000 & 0.022 & 0.043 & 0.000 & 0.030 & 0.078 & 0.000 & 0.015 & 0.959 & 0.680 & 0.904 & 0.181 \\
\hline Obs & 494 & 267 & 227 & 494 & 267 & 227 & 494 & 267 & 227 & 494 & 267 & 227 & 494 & 267 & 227 \\
\hline Nr. of id & 28 & 15 & 13 & 28 & 15 & 13 & 28 & 15 & 13 & 28 & 15 & 13 & 28 & 15 & 13 \\
\hline F statistic & 134 & 148 & 85 & 889 & 514 & 1023 & 79 & 45 & 111 & 1896 & 948 & 525 & 1002 & 347 & 456 \\
\hline Prob $>$ F & 0.000 & 0.000 & 0.000 & 0.000 & 0.000 & 0.000 & 0.000 & 0.000 & 0.000 & 0.000 & 0.000 & 0.000 & 0.000 & 0.000 & 0.000 \\
\hline
\end{tabular}


When applying the LSDV model starting from FEM and considering the country's dummy variables, the significant variables are economic freedom, investments, population change, trade, tertiary education attendance, government expenditures, rule of law, as well as control of corruption. When controlling for serial correlation, heteroscedasticity, and cross-section dependence using the PCSE model, only variables CPI, democracy index, population change, trade openness, voice and accountability, and control of corruption are considered to have a significant influence on economic wealth when analyzing the whole EU28 sample, due to their lower $p$-value in comparison with the significance threshold (see Table 3).

In the case of OMS, in the LSDV scenario, the same variables were considered significant as in the EU28 sample, except for the economic freedom variable. When applying the FGLS model for this specific sample, only democracy index, level of investment, trade openness, education attainment, rule of law, and control of corruption had a significant influence on economic wealth. When analyzing the significance of each variable in the NMS subsample using the LSDV model, 9 of the 12 independent variables were found significant, except for the economic freedom index, government expenditures, and voice and accountability variable. However, when performing FGLS, the democracy index, as well as control of corruption, lost their significance in favor of the government expenditure variable.

Summarizing all mentioned above, the corruption perception index has a significant influence on the GDP per capita dependent variable for both EU28 as well as NMS samples when using the PCSE/FGLS model. The lack of significance of CPI rescaled variable ( $p$-value $=0.532)$ when controlling for serial correlation, heteroscedasticity, and crosssection dependence in case of OMS subsample, as well as in LSDV model applied to the EU28 sample, should not determine the exclusion of this variable from the model, because it has a significant theoretical importance. Another way to prove the importance of this variable for analyzed models, as well as the importance of other independent variables, is through the coefficient of determination $\left(\mathrm{R}^{2}\right)$. In the fixed effects model performed on the whole sample, the "rho" indicator suggests that $99.16 \%$ of the variance $(98.44 \%$ in OMS sample and $96.09 \%$ in NMS sample, respectively) is due to differences between panels, supporting the use of country dummy variables. When considering the model that uses dummy variables to absorb the particularities of each country, the R square varies from 0.994 for the model considering the whole EU (variables chosen in the model explained $99.4 \%$ of GDP per capita level, while only $0.6 \%$ could be explained by other factors) to 0.990 for OMS and 0.984 for NMS samples. In the case of the PCSE model, the determination coefficient is around 0.759 when considering the whole EU28 sample, and 0.872 and 0.671 , respectively, in the hypothetical case of also applying the PCSE model for OMS and NMS samples.

Evaluating the regression tables (see Appendix B), it can be easily observed that in the PCSE model, in all three scenarios, there was a negative relationship between levels of corruption (cpi_rescaled) and economic wealth (gdpcap), as initially expected. Accordingly, corruption reduced economic wealth in all considered hypotheses of our analysis, meaning that a one-unit increase reduced economic wealth by approximately 1258.948 Euro/capita in European Union, by 164.756 Euro/capita in EU old member states, and by 631.281 Euro/capita in new member states, emphasizing that the new European Union member states with lower GDP suffered more from corruption in comparison with older EU states. For the whole of the EU28 samples, negative influences on GDP were present in the case of total fixed assets and government expenditures, however, none of them proved a significant influence, considering their $p$ values. The latter's effect can be justified as government expenses are mainly composed of current expenses (expenses with protection and social assistance), granting less importance to capital expenditures.

Nevertheless, the estimated coefficients for all the other considered variables were positive, in line with expected influences for the EU28 sample, while, for example, a change of one unit in democracy index or in corruption control increases GDP per capita by 7744.276 Euro or by 5203.325 Euro, respectively, whereas a one-unit modification in trade 
openness for the EU28 sample contributes to economic wealth by merely 72.965 Euro/capita. Moreover, for the EU28 sample, all variables capturing the quality of governance were proven to have a positive impact on economic wealth, with higher levels of governance performances synonymous with low levels of rent-seeking and personal interest and political pressures on state administration contributing to economic wealth, as emphasized by public choice theory.

In the case of OMS states, when controlling for serial correlation, heteroscedasticity and cross-section dependence using FGLS models, apart from cpi, economic freedom, and government expenditure, which have unexpected signs but are not statistically significant in the model as shown by their $p$ values, all variables contributed in a positive manner to economic wealth. The same scenario applies for the NMS sample, where unexpected signs were encountered in the case of democracy index, voice and accountability, and control of corruption variables.

Additionally, this study also points to variables that increase economic wealth in all the EU despite the sample size. Thus, population change, trade openness, tertiary education attainment, government effectiveness, and rule of law have a positive contribution on economic wealth in all scenarios, whether PCSE or FGLS model were applied.

\section{Discussion}

The link between corruption and economic wealth aroused the interest of various researchers, the subject being of interest, regardless of the decade, due to the persistence of corruption among politicians and in public structures, as emphasized by public choice thinkers.

The regression results using the adapted model of Thach, Duong, and Oanh [1] are in line with reference literature in the sense that corruption is proven to impose serious costs on economic wealth and growth $[16,18,47]$. Nevertheless, as Thach, Duong, and Oanh [1] maintain, some research in this field emphasizes a possible positive correlation between corruption and economic wealth. This can be explained by corruption, in the view of skipping some inefficient bureaucratic procedures, being able to speed up economic activities and, somehow, their efficiency. However, in the opinion of the aforementioned authors, these arguments are not particularly valid and significant, especially in the case analyzed, where corruption and rent-seeking at higher levels in public administration are seen as a significant impediment for the healthy sustainable development of a state with important consequences for economic growth and economic wealth.

In comparison with the original model, the differences are present in the influences of independent variables. For example, in the original study, the level of investment, as well as government expenditure, were expected to manifest positive influences on the GDP per capita variable [1]. In our case, however, these two variables in the PCSE model for the whole EU28 sample seemed to have a negative result on economic wealth, yet not at a significant level. This can be argued through the view of "selective investments", as not all investment expenses induce economic growth, with some of them representing merely immobilizations of resources, as well as poor capital management. This is similar to the concept of capital intensity from the private economy, where, in the case of some small and medium enterprises some investments are perceived as a way to reduce or avoid payment of profit tax, yet they do not produce useful effects on sales and profits. Moreover, government expenditures can easily induce a negative effect on economic growth if the government spends money in areas that do not promote sustainable development and competitiveness, prioritizing mainly the current expenditures. On the other hand, variables such as population change and education attainment, which reflect the human capital dimension of economic wealth, turned out to have a positive influence on economic development, in contrast to the influence they pose on the original model.

The other four variables introduced in this first model proved to have a positive influence on the GDP per capita, emphasizing the importance of proper governmental performances, in line with findings of Sharma and Mitra, who pointed out that regulatory 
quality, as well as control of corruption, have a significant positive influence on economic growth [14].

The main results of our study emphasize a negative relationship between corruption and economic wealth (GDP/capita) for all EU member states. However, in comparison to older EU member states, new European member states with lower GDP are more prone to corruption, this phenomenon affecting economic wealth to a greater extent. The main reason for this divergence in comparison with the OMS resides in the institutional quality, as well as in the historical background, of NMS in terms of democracy, culture and population education, and trust in the state apparatus, as concluded by Blagojevic and Damijan [58] and Bakowski and Varonova [59]. As stated by Van Der Hoek [60], high levels of corruption expose enterprises and businesses to additional risks, and have a burdensome impact on economic growth, especially in the new post-communist member countries. Even though it was mandatory for these countries to align their regulations with those imposed by the European Union at the time of accession, they still need to improve their reforms regarding corruption [61]. Moreover, the analysis conducted by Ropret, Aristovnik, and Kovač [62] also pointed out significant differences between the NMS and OMS in terms of regulatory quality, OMS being more concerned with the rule of law and its connection with the concepts of efficiency.

Shera, Dosti, and Grabova [12] also determined a negative significant impact of corruption upon economic growth, using both FEM and REM regressions to analyze 22 developing countries. Moreover, bureaucracy was demonstrated to manifest a negative impact on economic growth in the study of Libman [63], where other variables, such as education, trade openness, and investments, have proven to have a significant positive influence on economic development in the case of Russian regions, using OLS regression. The same conclusion was highlighted by the analysis presented in this paper for the EU states. The negative long-term effect of corruption on GDP per capita was also concluded by Al Qudah, Zouaoui, and Aboelsoud [16] when studying this phenomenon through an ARDL approach for Tunisia. Similar results regarding corruption and rent-seeking phenomena were highlighted by Alfada [18] while analyzing the effect of corruption on economic growth in Indonesia. Corruption was also negatively associated with growth in the study of Anh, Minh, and Tran-Nam [47] after performing OLS regression for Vietnam. In summary, many studies highlighted the negative effects of corruption and rent-seeking on economic growth, the current study's results being in line with previous papers in this field.

Corruption is a phenomenon whose implications are felt in all spheres of the economy, with effects later projected on the economic well-being of every state. Due to this, and given the results of our regression, economic and anti-corruption policies must aim at reforming public institutions' structure and activity, improving governance quality, as well as the public sector's efficiency.

The main limitation of the study refers to the sample size. Even though, from a statistical point of view, the sample is significant, the period was limited to the 2000-2019 interval due to lack of data from previous years, especially for the variables capturing governance quality. Furthermore, the methodology can be improved in further research, perhaps with the use of moderator variables, to better explain the link between corruption, rent-seeking behavior, and economic wealth. Moreover, the model can be completed with other variables reflecting the quality of government or variables that are main drivers for economic growth (such as productivity, research, and development) to increase the explained variance; however, it is important to consider the dimension of the samples and observe the statistical requirements regarding database size.

\section{Conclusions}

Corruption is a complex problem that exists in every country of the European Union (28) that negatively affects both society and economic wealth, yet in a different way depending on the development level of analyzed countries. There are lots of studies and research 
with corruption and its influences as the main subject, known as a negative phenomenon observed both in developed and developing countries around the world.

The main finding of our research reveals a negative relationship between corruption and economic wealth (GDP/capita) for all EU member states. New EU member states, with a lower GDP, suffer more from corruption in comparison with the older EU states.

Negative influences on GDP are present in case the of total fixed asset and government expenditures (the composition of expenditures can be an explanation); however, not at a significant level. On the other hand, variables such as population change and education attainment, which reflect the human capital dimension on economic wealth, have a positive influence on economic wealth.

All the other considered variables have a positive influence in relationship with economic wealth.

For all EU member states, all variables capturing the governance quality have proven to have a positive impact on economic wealth, as higher levels of governance performances favor lower levels of rent-seeking, of personal interests, and political pressures on state administration. All these circumstances contribute to economic wealth, as emphasized by public choice theory proponents.

It also seems that population change, trade openness, tertiary education attainment, government effectiveness, and rule of law have a positive contribution on economic wealth in all scenarios for both PCSE and FGLS models. Regulatory quality, as well as corruption control, have significant positive influences on economic wealth.

Reform, or at least an efficiency increase of NMS' public institutions, becomes necessary, but as Ostrom and Ostrom [64] mentioned, this reform needs an assessment of institutions' performances through a systematic and comparative analysis and not a naive separation of institutions into "good" or "bad".

This research contributes to reference literature with a fresh approach from a public choice perspective and can be considered by policy-makers as a reference and an incentive to promote appropriate measures to support the creation of sustainable development for all the parties involved, including themselves, but obviously mainly for the population they represent.

The topic of corruption and its impact is too large to be covered in this paper. A future development of the research will be to study the impact of nepotism and poor selection of public sector's employees on emigration, economic growth, and economic wellbeing, especially in the case of new member states.

Author Contributions: Conceptualization, G.D. and C.N.; methodology, G.D., C.N. and M.B.; software, C.N. and M.B.; validation, G.D. and M.S.D.; formal analysis, G.D., C.N. and M.B.; investigation, G.D., C.N. and M.S.D.; resources, G.D., C.N. and M.B.; data curation, C.N. and M.B.; writing—original draft preparation, G.D., C.N., M.S.D. and M.B.; writing—review and editing, G.D., M.S.D., C.N. and M.B.; visualization, C.N. and M.B.; supervision, G.D. and M.S.D.; project administration, G.D. and M.S.D. All authors have read and agreed to the published version of the manuscript.

Funding: This research received no external funding.

Institutional Review Board Statement: Not applicable.

Informed Consent Statement: Not applicable.

Data Availability Statement: The data presented in this study are available on request from the corresponding author.

Conflicts of Interest: The authors declare no conflict of interest. 


\section{Appendix A. Descriptive Statistics}

Table A1. Descriptive statistics for the OMS sample.

\begin{tabular}{cccccc}
\hline Variable & Obs & Mean & Std. Dev. & Min & Max \\
\hline gdpcap & 300 & $35,018.270$ & $14,230.33$ & $16,050.00$ & $84,420.00$ \\
cpi_rescaled & 300 & 2.552 & 1.505 & 0.000 & 6.600 \\
democ & 300 & 0.792 & 0.027 & 0.737 & 0.855 \\
ecfreed & 285 & 7.748 & 0.280 & 6.627 & 8.500 \\
investm & 300 & 21.255 & 3.777 & 10.100 & 45.600 \\
popchange & 300 & 5.776 & 6.064 & -7.500 & 30.900 \\
trade & 300 & 105.978 & 72.742 & 45.419 & 408.362 \\
ed & 296 & 29.474 & 8.761 & 8.800 & 47.300 \\
govexp & 300 & 47.406 & 6.230 & 24.500 & 65.100 \\
voice & 285 & 1.343 & 0.224 & 0.619 & 1.801 \\
goveff & 285 & 1.499 & 0.500 & 0.198 & 2.354 \\
rlaw & 285 & 1.496 & 0.484 & 0.084 & 2.100 \\
contrcorr & 285 & 1.539 & 0.680 & -0.189 & 2.470 \\
\hline
\end{tabular}

Data source: authors' processing.

Table A2. Descriptive statistics for the NMS sample.

\begin{tabular}{cccccc}
\hline Variable & Obs & Mean & Std. Dev. & Min & Max \\
\hline gdpcap & 258 & $12,016.430$ & 5006.384 & 3010.00 & $24,680.00$ \\
cpi_rescaled & 253 & 4.992 & 1.005 & 2.600 & 7.400 \\
democ & 260 & 0.687 & 0.094 & 0.356 & 0.810 \\
ecfreed & 247 & 7.441 & 0.466 & 5.550 & 8.124 \\
investm & 260 & 23.134 & 4.267 & 12.900 & 37.300 \\
popchange & 260 & -1.123 & 9.537 & -35.000 & 41.700 \\
trade & 260 & 129.607 & 51.943 & 48.521 & 322.677 \\
ed & 258 & 23.249 & 8.670 & 5.400 & 44.700 \\
govexp & 260 & 41.436 & 5.116 & 33.200 & 60.300 \\
voice & 247 & 0.864 & 0.260 & 0.220 & 1.373 \\
goveff & 247 & 0.717 & 0.413 & -0.373 & 1.564 \\
rlaw & 247 & 0.687 & 0.441 & -0.260 & 1.630 \\
contrcorr & 247 & 0.450 & 0.427 & -0.491 & 1.542 \\
\hline
\end{tabular}

Data source: authors' processing.

\section{Appendix B. Regression Results}

Table A3. Regression results for the EU28 sample.

\begin{tabular}{cccccc}
\hline & \multicolumn{2}{c}{ Dependent Variable: gdpcap } & & & \\
\hline Independent Variables & Pooled OLS & REM & FEM & LSDV & PCSE \\
\hline cpi_rescaled & $-2363.223^{* * *}$ & -221.386 & -187.578 & -187.578 & $-1258.948^{* * *}$ \\
& $(909.212)$ & $(177.170)$ & $(170.021)$ & $(170.021)$ & $(378.746)$ \\
\hline democ & $21,314.458^{* *}$ & 1282.437 & 1349.422 & 1349.422 & $7744.276^{*}$ \\
& $(8285.237)$ & $(2317.813)$ & $(2227.248)$ & $(2227.248)$ & $(4602.687)$ \\
\hline ecfreed & 490.945 & $-941.750^{* *}$ & $-830.409^{* *}$ & $-830.409 * *$ & 561.669 \\
& $(1584.075)$ & $(410.186)$ & $(394.429)$ & $(394.429)$ & $(791.131)$ \\
\hline investm & $-340.920^{* * * *}$ & $200.644^{* * *}$ & $203.610^{* * *}$ & $203.610^{* * *}$ & -70.027 \\
& $(94.393)$ & $(26.739)$ & $(25.684)$ & $(25.684)$ & $(56.147)$ \\
\hline popchange & $474.052^{* * *}$ & $59.831^{* * *}$ & $55.796^{* * *}$ & $55.796^{* * *}$ & $155.701^{* * *}$ \\
& $(54.321)$ & $(15.223)$ & $(14.630)$ & $(14.630)$ & $(34.829)$ \\
\hline trade & $70.063^{* * *}$ & $33.807^{* * *}$ & $32.907^{* * *}$ & $32.907^{* * *}$ & $72.965^{* * *}$ \\
& $(6.854)$ & $(5.219)$ & $(5.106)$ & $(5.106)$ & $(12.269)$ \\
\hline ed & 37.093 & $251.085^{* * *}$ & $249.161^{* * *}$ & $249.161^{* * *}$ & 75.959 \\
& $(54.488)$ & $(19.839)$ & $(19.258)$ & $(19.258)$ & $(62.157)$ \\
\hline
\end{tabular}


Table A3. Cont.

\begin{tabular}{|c|c|c|c|c|c|}
\hline \multicolumn{6}{|c|}{ Dependent Variable: gdpcap } \\
\hline Independent Variables & Pooled OLS & REM & FEM & LSDV & PCSE \\
\hline govexp & $\begin{array}{c}229.641 \text { *** } \\
(79.688)\end{array}$ & $\begin{array}{c}-171.233^{* * *} \\
(24.686)\end{array}$ & $\begin{array}{c}-178.300^{* * *} \\
(23.733)\end{array}$ & $\begin{array}{c}-178.300 * * * \\
(23.733)\end{array}$ & $\begin{array}{l}-1.472 \\
(43.124)\end{array}$ \\
\hline voice & $\begin{array}{c}4,133.245 \\
(3,968.853)\end{array}$ & $\begin{array}{l}-496.507 \\
(891.573)\end{array}$ & $\begin{array}{l}-735.420 \\
(856.647)\end{array}$ & $\begin{array}{l}-735.420 \\
(856.647)\end{array}$ & $\begin{array}{c}3519.835 * * \\
(1530.576)\end{array}$ \\
\hline goveff & $\begin{array}{c}-6,182.130 \text { *** } \\
(2,003.049)\end{array}$ & $\begin{array}{l}-231.975 \\
(530.444)\end{array}$ & $\begin{array}{l}-372.798 \\
(510.263)\end{array}$ & $\begin{array}{l}-372.798 \\
(510.263)\end{array}$ & $\begin{array}{c}810.500 \\
(866.493)\end{array}$ \\
\hline rlaw & $\begin{array}{c}-4831.085^{* *} \\
(2454.254)\end{array}$ & $\begin{array}{c}3309.024^{* * *} \\
(692.314)\end{array}$ & $\begin{array}{c}3237.978 * * * \\
(665.088)\end{array}$ & $\begin{array}{c}3237.978 * * * \\
(665.088)\end{array}$ & $\begin{array}{c}2108.564 \\
(1293.559)\end{array}$ \\
\hline contrcorr & $\begin{array}{l}11,007.441 * * * \\
(2544.982)\end{array}$ & $\begin{array}{l}-841.093 \\
(583.364)\end{array}$ & $\begin{array}{c}-1097.187 * \\
(561.591)\end{array}$ & $\begin{array}{c}-1097.187 * \\
(561.591)\end{array}$ & $\begin{array}{c}5203.325^{* * *} \\
(1116.514)\end{array}$ \\
\hline Constant & $\begin{array}{c}-3356.935 \\
(16,412.422) \\
\end{array}$ & $\begin{array}{c}21,805.191^{* * *} \\
\quad(4292.427)\end{array}$ & $\begin{array}{c}22,033.755^{* * * *} \\
(3780.915)\end{array}$ & $\begin{array}{c}34,211.539 * * * \\
(3812.563)\end{array}$ & $\begin{array}{l}-3172.333 \\
(7701.158)\end{array}$ \\
\hline Observations & 494 & 494 & 494 & 494 & 494 \\
\hline R-squared & 0.770 & & 0.675 & 0.994 & 0.759 \\
\hline Number of id & 28 & 28 & 28 & 28 & 28 \\
\hline F Statistics & 134.00 & 889.54 & 78.75 & 1895.57 & 1001.52 \\
\hline P value & 0.0000 & 0.0000 & 0.0000 & 0.0000 & 0.0000 \\
\hline White test & 428.80 & & & & \\
\hline Test parm & 12.40 & & & & \\
\hline Breusch-Pagan Lagrangian multiplier test & & 2553.98 & & & \\
\hline Hausman test & & & 78.75 & & \\
\hline Chow test & & & 49.60 & & \\
\hline Breusch-Pagan LM test of independence & & & 979.055 & & \\
\hline Wald test & & & 7233.69 & & \\
\hline Pesaran test & & & 11.865 & & \\
\hline Wooldridge test & & & 374.965 & & \\
\hline
\end{tabular}

Table A4. Regression results for the OMS sample.

\begin{tabular}{cccccc}
\hline & \multicolumn{2}{c}{ Dependent Variable: gdpcap } & & & \\
\hline Independent Variables & Pooled OLS & REM & FEM & LSDV & FGLS \\
\hline cpi_rescaled & $-2144.060^{* *}$ & -245.209 & -47.083 & -47.083 & -164.756 \\
& $(992.557)$ & $(345.291)$ & $(333.694)$ & $(333.694)$ & $(263.376)$ \\
\hline democ & $62,630.848^{* * *}$ & $12,491.117$ & $14,814.810$ & $14,814.810$ & $20,398.182^{* *}$ \\
& $(15,676.214)$ & $(10,938.691)$ & $(10,598.215)$ & $(10,598.215)$ & $(8953.392)$ \\
\hline ecfreed & $2,912.503$ & -1643.462 & -1356.692 & -1356.692 & -970.254 \\
& $(1964.739)$ & $(1104.888)$ & $(1060.091)$ & $(1060.091)$ & $(908.114)$ \\
\hline investm & $-427.284^{* * *}$ & $431.690^{* * *}$ & $453.519^{* * *}$ & $453.519 * * *$ & $138.466^{* *}$ \\
& $(116.131)$ & $(60.259)$ & $(57.880)$ & $(57.880)$ & $(60.963)$ \\
\hline popchange & $579.019 * * *$ & -45.888 & $-53.074 *$ & $-53.074 *$ & 41.682 \\
& $(80.378)$ & $(30.805)$ & $(29.423)$ & $(29.423)$ & $(29.019)$ \\
\hline trade & $134.548^{* * *}$ & $53.632 * * *$ & $42.790^{* * *}$ & 42.790 *** & $98.321^{* * * *}$ \\
& $(6.954)$ & $(8.671)$ & $(8.721)$ & $(8.721)$ & $(8.869)$ \\
\hline
\end{tabular}


Table A4. Cont.

\begin{tabular}{|c|c|c|c|c|c|}
\hline \multicolumn{6}{|c|}{ Dependent Variable: gdpcap } \\
\hline Independent Variables & Pooled OLS & REM & FEM & LSDV & FGLS \\
\hline ed & $\begin{array}{c}-86.431 \\
(46.847)\end{array}$ & $\begin{array}{c}222.746^{* * *} \\
(30.322)\end{array}$ & $\begin{array}{c}237.172^{* * *} \\
(29.915)\end{array}$ & $\begin{array}{c}237.172^{* * *} \\
(29.915)\end{array}$ & $\begin{array}{c}178.242^{* * *} \\
(36.099)\end{array}$ \\
\hline govexp & $\begin{array}{c}211.753 * * * \\
(77.955)\end{array}$ & $\begin{array}{c}-194.640^{* * *} \\
(41.230)\end{array}$ & $\begin{array}{c}-197.073^{* * *} \\
(39.518)\end{array}$ & $\begin{array}{c}-197.073^{* * *} \\
(39.518)\end{array}$ & $\begin{array}{l}-53.735 \\
(38.572)\end{array}$ \\
\hline voice & $\begin{array}{c}2708.622 \\
(3794.889)\end{array}$ & $\begin{array}{c}-645.835 \\
(1334.799)\end{array}$ & $\begin{array}{l}-1011.603 \\
(1,275.109)\end{array}$ & $\begin{array}{l}-1011.603 \\
(1275.109)\end{array}$ & $\begin{array}{l}1051.970 \\
(908.813)\end{array}$ \\
\hline goveff & $\begin{array}{c}-3,667.378 * \\
(1949.478)\end{array}$ & $\begin{array}{l}-289.659 \\
(793.012)\end{array}$ & $\begin{array}{l}-446.583 \\
(761.706)\end{array}$ & $\begin{array}{l}-446.583 \\
(761.706)\end{array}$ & $\begin{array}{c}349.250 \\
(592.446)\end{array}$ \\
\hline rlaw & $\begin{array}{c}2736.451 \\
(2469.974)\end{array}$ & $\begin{array}{c}2656.335^{* *} \\
(1199.150)\end{array}$ & $\begin{array}{l}1971.851 * \\
(1158.421)\end{array}$ & $\begin{array}{l}1,971.851 * \\
(1158.421)\end{array}$ & $\begin{array}{c}1933.103^{* *} \\
(879.172)\end{array}$ \\
\hline contrcorr & $\begin{array}{c}-86.393 \\
(2852.839)\end{array}$ & $\begin{array}{c}-2042.263 * * \\
(972.580)\end{array}$ & $\begin{array}{c}-1966.569 * * \\
(929.580)\end{array}$ & $\begin{array}{c}-1966.569 * * \\
(929.580)\end{array}$ & $\begin{array}{c}2304.013 * * * \\
(767.560)\end{array}$ \\
\hline Constant & $\begin{array}{c}-50,011.945^{* *} \\
(21,903.113)\end{array}$ & $\begin{array}{c}27,146.028^{* *} \\
(11,870.856)\end{array}$ & $\begin{array}{c}24,608.720 * * \\
(11,297.898)\end{array}$ & $\begin{array}{c}27,118.844^{* *} \\
(11,082.228)\end{array}$ & $\begin{array}{c}1282.642 \\
(10,669.282)\end{array}$ \\
\hline Observations & 267 & 267 & 267 & 267 & 267 \\
\hline R-squared & 0.875 & & 0.692 & 0.990 & $\begin{array}{l}0.872 \text { (in } \\
\text { PCSE) }\end{array}$ \\
\hline Number of id & 15 & 15 & 15 & 15 & 15 \\
\hline $\mathrm{F}$ & 148.11 & 514.15 & 45.02 & 947.82 & 346.59 \\
\hline Prob $>$ F & 0.0000 & 0.0000 & 0.0000 & 0.0000 & 0.0000 \\
\hline White test & 223.64 & & & & \\
\hline Test parm & 16.43 & & & & \\
\hline $\begin{array}{l}\text { Breusch-Pagan and Pagan Lagrangian } \\
\text { multiplier test }\end{array}$ & & 742.57 & & & \\
\hline Hausman test & & & 34.03 & & \\
\hline Chow test & & & 205.11 & & \\
\hline Breusch-Pagan LM test of independence & & & 362.202 & & \\
\hline Wald test & & & 1889.47 & & \\
\hline Pesaran test & & & 7.704 & & \\
\hline Wooldridge test & & & 177.679 & & \\
\hline
\end{tabular}

${ }^{* * *} p<0.01,{ }^{* *} p<0.05,{ }^{*} p<0.1$, Standard errors in parentheses. Data source: authors' processing.

Table A5. Regression results for the NMS sample.

\begin{tabular}{|c|c|c|c|c|c|}
\hline \multicolumn{6}{|c|}{ Dependent Variable: gdpcap } \\
\hline Independant Variables & Pooled OLS & REM & FEM & LSDV & FGLS \\
\hline cpi_rescaled & $\begin{array}{l}-407.406 \\
(351.922)\end{array}$ & $\begin{array}{l}-407.406 \\
(351.922)\end{array}$ & $\begin{array}{c}-246.446^{*} \\
(129.989)\end{array}$ & $\begin{array}{l}-246.446 * \\
(129.989)\end{array}$ & $\begin{array}{c}-631.281^{* * *} \\
(170.566)\end{array}$ \\
\hline Democ & $\begin{array}{l}-2669.066 \\
(3661.963)\end{array}$ & $\begin{array}{l}-2669.066 \\
(3661.963)\end{array}$ & $\begin{array}{c}-7052.720 * * * \\
(1517.506)\end{array}$ & $\begin{array}{c}-7052.720 * * * \\
(1517.506)\end{array}$ & $\begin{array}{l}-2256.429 \\
(1801.404)\end{array}$ \\
\hline Ecfreed & $\begin{array}{l}-509.598 \\
(672.041)\end{array}$ & $\begin{array}{l}-509.598 \\
(672.041)\end{array}$ & $\begin{array}{c}335.717 \\
(253.416) \\
\end{array}$ & $\begin{array}{c}335.717 \\
(253.416)\end{array}$ & $\begin{array}{c}281.708 \\
(339.657) \\
\end{array}$ \\
\hline Investm & $\begin{array}{c}19.737 \\
(39.476)\end{array}$ & $\begin{array}{c}19.737 \\
(39.476)\end{array}$ & $\begin{array}{c}89.164^{* * *} \\
(16.554)\end{array}$ & $\begin{array}{c}89.164^{* * *} \\
(16.554)\end{array}$ & $\begin{array}{c}75.136^{* * *} \\
(21.373)\end{array}$ \\
\hline
\end{tabular}


Table A5. Cont.

\begin{tabular}{|c|c|c|c|c|c|}
\hline \multicolumn{6}{|c|}{ Dependent Variable: gdpcap } \\
\hline Independant Variables & Pooled OLS & REM & FEM & LSDV & FGLS \\
\hline popchange & $\begin{array}{l}281.991 * * * \\
(20.597)\end{array}$ & $\begin{array}{l}281.991 * * * \\
(20.597)\end{array}$ & $\begin{array}{c}102.741^{* * *} \\
(9.706)\end{array}$ & $\begin{array}{c}102.741^{* * *} \\
(9.706)\end{array}$ & $\begin{array}{c}106.829 * * * \\
(14.505)\end{array}$ \\
\hline Trade & $\begin{array}{l}-2.025 \\
(4.766)\end{array}$ & $\begin{array}{l}-2.025 \\
(4.766)\end{array}$ & $\begin{array}{c}22.996^{* * *} \\
(3.743)\end{array}$ & $\begin{array}{c}22.996^{* * *} \\
(3.743)\end{array}$ & $\begin{array}{c}23.788^{* * *} \\
(3.598)\end{array}$ \\
\hline $\mathrm{Ed}$ & $\begin{array}{c}99.159 * * * \\
(31.559)\end{array}$ & $\begin{array}{c}99.159 * * * \\
(31.559)\end{array}$ & $\begin{array}{c}171.166^{* * *} \\
(18.626)\end{array}$ & $\begin{array}{c}171.166^{* * *} \\
(18.626)\end{array}$ & $\begin{array}{c}83.609 * * * \\
(22.126)\end{array}$ \\
\hline Govexp & $\begin{array}{c}63.013 \\
(38.913) \\
\end{array}$ & $\begin{array}{c}63.013 \\
(38.913) \\
\end{array}$ & $\begin{array}{l}-8.215 \\
(20.288)\end{array}$ & $\begin{array}{l}-8.215 \\
(20.288)\end{array}$ & $\begin{array}{l}43.115^{*} \\
(22.369)\end{array}$ \\
\hline Voice & $\begin{array}{c}-4867.943^{* * *} \\
(1810.576)\end{array}$ & $\begin{array}{c}-4867.943 * * * \\
(1810.576)\end{array}$ & $\begin{array}{c}915.929 \\
(738.332)\end{array}$ & $\begin{array}{c}915.929 \\
(738.332)\end{array}$ & $\begin{array}{l}-725.834 \\
(823.609)\end{array}$ \\
\hline Goveff & $\begin{array}{c}4744.715^{* * *} \\
(927.316)\end{array}$ & $\begin{array}{c}4744.715^{* * *} \\
(927.316)\end{array}$ & $\begin{array}{l}911.220 * * \\
(449.890)\end{array}$ & $\begin{array}{l}911.220 * * \\
(449.890)\end{array}$ & $\begin{array}{c}1562.182 \text { *** } \\
(523.867)\end{array}$ \\
\hline Rlaw & $\begin{array}{c}4081.416^{* * *} \\
(1096.747)\end{array}$ & $\begin{array}{c}4081.416^{* * *} \\
(1096.747)\end{array}$ & $\begin{array}{c}2288.014^{* * *} \\
(531.342)\end{array}$ & $\begin{array}{c}2288.014^{* * *} \\
(531.342)\end{array}$ & $\begin{array}{c}1378.916^{* *} \\
(626.419)\end{array}$ \\
\hline Contrcorr & $\begin{array}{c}-740.273 \\
(1102.951)\end{array}$ & $\begin{array}{c}-740.273 \\
(1102.951)\end{array}$ & $\begin{array}{c}-817.825 * \\
(461.712)\end{array}$ & $\begin{array}{c}-817.825 * \\
(461.712)\end{array}$ & $\begin{array}{c}-79.750 \\
(518.433)\end{array}$ \\
\hline Constant & $\begin{array}{c}13,179.661 * * \\
(6510.617)\end{array}$ & $\begin{array}{c}13,179.661^{* *} \\
(6510.617)\end{array}$ & $\begin{array}{l}4260.868 * \\
(2404.853)\end{array}$ & $\begin{array}{c}-123.729 \\
(2386.717)\end{array}$ & $\begin{array}{c}4368.802 \\
(3267.881)\end{array}$ \\
\hline Observations & 227 & 227 & 227 & 227 & 227 \\
\hline R-squared & 0.827 & & 0.869 & 0.984 & $\begin{array}{l}0.671 \text { (in } \\
\text { PCSE) }\end{array}$ \\
\hline Number of id & 13 & 13 & 13 & 13 & 13 \\
\hline $\mathrm{F}$ & 85.25 & 1023.02 & 111.25 & 525.05 & 455.82 \\
\hline Prob $>F$ & 0.0000 & 0.0000 & 0.0000 & 0.0000 & 0.0000 \\
\hline White test & 184.61 & & & & \\
\hline Test parm & 17.64 & & & & \\
\hline $\begin{array}{l}\text { Breusch-Pagan and Pagan Lagrangian } \\
\text { multiplier test }\end{array}$ & & 0.00 & & & \\
\hline Hausman test & & & 188.76 & & \\
\hline Chow test & & & 167.74 & & \\
\hline Breusch-Pagan LM test of independence & & & 188.177 & & \\
\hline Wald test & & & 75.33 & & \\
\hline \multicolumn{6}{|l|}{ Pesaran test } \\
\hline Wooldridge test & & & 131.877 & & \\
\hline
\end{tabular}

${ }^{* * *} p<0.01,{ }^{* *} p<0.05,{ }^{*} p<0.1$, Standard errors in parentheses. Data source: authors' processing.

\section{References}

1. Thach, N.N.; Duong, M.B.; Oanh, T.T.K. Effects of corruption on economic growth-empirical study of Asia countries. Imp. J. Interdiscip. Res. 2017, 7, 791-804. Available online: https://www.researchgate.net/profile/Nguyen-Thach/publication/325683 331_Effects_of_Corruption_on_Economic_Growth_-_Empirical_Study_of_Asia_Countries/links/5b1e2bdd45851587f29f6f0c/ Effects-of-Corruption-on-Economic-Growth-Empirical-Study-of-Asia-Countries.pdf. (accessed on 20 February 2021).

2. $\quad$ Dincă, G. Public Choice Theory; Infomarket: Brașov, Romania, 2006; pp. 111-128.

3. Buchanan, J.M.; Tullock, G. The Calculus of Consent: Logical Foundations of Constitutional Democracy; University of Michigan Press: Ann Arbor, MI, USA, 1962.

4. Buchanan, J.M. Economics: Between Predictive Science and Moral Philosophy; Clarendon Press: Oxford, UK, 1987.

5. Anechiarico, F.; Jocobs, J.B. Visions of corruption control and the evolution of American public administration. Public Adm. Rev. 1994, 54, 463-473. [CrossRef] 
6. Aidt, T.S. Rent seeking and the economics of corruption. Const. Political Econ. 2016, 27, 142-157. Available online: https: / /link.springer.com/article/10.1007/s10602-016-9215-9.. [CrossRef]

7. Lambsdorff, J.G. Corruption and Rent-Seeking. Public Choice 2002, 113, 97-125. [CrossRef]

8. Mbaku, J.M. Corruption Cleanups in Africa. J. Asian Afr. Stud. 2008, 43, 427-456. [CrossRef]

9. Rasheed, S. Ethics and Accountability in African Public Services; ICIPE Science Press: Nairobi, Kenya, 1993 ; pp. $43-63$.

10. Mauro, P. Corruption and Growth. Q. J. Econ. 1995, 110, 681-712. [CrossRef]

11. Bentzen, J.S. How Bad is Corruption? Cross-country Evidence of the Impact of Corruption on Economic Prosperity. Rev. Dev. Econ. 2012, 16, 167-184. [CrossRef]

12. Shera, A.; Dosti, B.; Grabova, P. Corruption impact on Economic Growth: An empirical analysis. J. Econ. Dev. Manag. IT Financ. Mark. 2014, 6, 57-77.

13. Bayar, Y.; Odabas, H.; Sasmaz, M.U.; Ozturk, O.F. Corruption and shadow economy in transition economies of European Union countries: A panel cointegration and causality analysis. Econ. Res. -Ekon. Istraživanja 2018, 31, 1940-1952. [CrossRef]

14. Sharma, C.; Mitra, A. Corruption and Economic Growth: Some New Empirical Evidence from a Global Sample. J. Int. Dev. 2019, 31, 691-719. [CrossRef]

15. Dang, Q.V. The impact of corruption on provincial development performance in Vietnam. Contemp. Crises 2016, 65, 325-350. [CrossRef]

16. Al Qudah, A.; Zouaoui, A.; Aboelsoud, M.E. Does corruption adversely affect economic growth in Tunisia? ARDL approach. J. Money Laund. Control. 2020, 23, 38-54. [CrossRef]

17. Venard, B. Institutions, Corruption and Sustainable Development. Econ. Bull. 2013, 33, 2545-2562. Available online: https: //hal-audencia.archives-ouvertes.fr/hal-00874275/file/Venard_Economics_Bulletin_2013.pdf (accessed on 2 April 2021).

18. Alfada, A. The destructive effect of corruption on economic growth in Indonesia: A threshold model. Heliyon 2019, 5, e02649. [CrossRef]

19. Mohommad, A.; Singh, A.; Jain-Chandra, S. Inclusive Growth, Institutions, and the Underground Economy. IMF Work. Pap. 2012, 12, 1. [CrossRef]

20. Dreher, A.; Schneider, F. Corruption and the shadow economy: An empirical analysis. Public Choice 2010, 144, 215-238. [CrossRef]

21. Hibbs, D.A.; Piculescu, V. Institutions, Corruption and Tax Evasion in the Unofficial Economy; Department of Economics: Göteborg, Sweden, 2005.

22. Drury, A.C.; Krieckhaus, J.; Lusztig, M. Corruption, Democracy, and Economic Growth. Int. Politi-Sci. Rev. 2006, 27, 121-136. [CrossRef]

23. Neudorfer, N.S. Commodities and corruption-How the middle class and democratic institutions lead to less corruption in resource-rich countries. Resour. Policy 2018, 58, 175-191. [CrossRef]

24. Costa, C.J.; Garcia-Cintado, A.C. Rent-seeking in an emerging market: A DSGE approach. Econ. Syst. 2021, 45, 100775. [CrossRef]

25. Acemoglu, D.; Verdier, T. Property Rights, Corruption and the Allocation of Talent: A General Equilibrium Approach. Econ. J. 1998, 108, 1381-1403. [CrossRef]

26. Houston, D. Can Corruption Ever Improve an Economy? Cato J. 2007, 27, 325-342.

27. Swaleheen, M.; Stansel, D. Economic Freedom, Corruption, and Economic Growth. Cato J. 2007, $27,343-358$.

28. Liu, C.; Moldogaziev, T.T.; Mikesell, J.L. Corruption and State and Local Government Debt Expansion. Public Adm. Rev. 2017, 77, 681-690. [CrossRef]

29. Zhang, Y.; Kim, M.-H. Do Public Corruption Convictions Influence Citizens' Trust in Government? The Answer Might Not Be a Simple Yes or No. Am. Rev. Public Adm. 2017, 48, 685-698. [CrossRef]

30. Capasso, S.; Santoro, L. Active and passive corruption: Theory and evidence. Eur. J. Politi-Econ. 2018, 52, 103-119. [CrossRef]

31. Murphy, K.M.; Shleifer, A.; Vishny, R.W. Why Is Rent-Seeking So Costly to Growth? Am. Econ. Rev. 2008, 83, 213-218. [CrossRef]

32. Alesina, A.; Angeletos, G.-M. Fairness and Redistribution. Am. Econ. Rev. 2005, 95, 960-980. [CrossRef]

33. Tullock, G. The Welfare Costs of Tariffs, Monopolies, and Theft. West. Econ. J. 1967, 5, 224-232. [CrossRef]

34. Krueger, A.O. The political economy of the rent-seeking society. Am. Econ. Rev. 1974, 64, 291-303.

35. Tollison, R.D. The economic theory of rent seeking. Public Choice 2012, 152, 73-82. [CrossRef]

36. Iqbal, N.; Daly, V. Rent seeking opportunities and economic growth in transitional economies. Econ. Model. 2014, 37, 16-22. [CrossRef]

37. Fisher, F. Restore the Health of Your Organization: A practical Guide to Curing and Preventing Corruption in Local Governments and Communities; United Nations Human Settlements Programme (UN-HABITAT) and Partners Foundation for Local Development (FPDL): Nairobi, Keyna, 2006.

38. Schwartz, H. Public Choice Theory and Public Choices: Bureaucrats and State Reorganization in Australia, Denmark, New Zealand and Sweden in the 1980s. Adm. Soc. 1994, 26, 48-77. [CrossRef]

39. Olson, M. The Logic of Collective Action; Palgrave Macmillan: London, UK, 2009; pp. 61-69.

40. Stigler, G.J. The Theory of Economic Regulation. Bell J. Econ. Manag. Sci. 1971, 2, 137-146. [CrossRef]

41. Butler, E. Public Choice-A Primer. Institute of Economic Affairs Occasional Paper 2012, 147. Available online: https://papers. ssrn.com/Sol3 / papers.cfm?abstract_id=2028989 (accessed on 1 June 2021).

42. Jain, A.K. Economics of Corruption; Springer Science \& Business Media: Berlin, Germany, 1998; pp. 13-34. 
43. Lonescu, L.; Robertson, K. Efficient Bureaucracy in the Public Sector for Safe Environment in Romania; Economic Series; Annals of Spiru Haret University: Bucharest, Romania, 2016; Available online: https:/ / papers.ssrn.com/sol3/papers.cfm?abstract_id=2878024 (accessed on 15 January 2021).

44. Downs, A. An Economic Theory of Democracy; Harper and Row: New York, NY, USA, 1957.

45. Popescu, I. The Expansion of European Bureaucracy. CES Work. Pap. 2011, 3, 415-428. Available online: https://www.econstor. eu/bitstream/10419/198134/1/ceswp-v03-i3-p415-428.pdf (accessed on 20 February 2021).

46. Van, G. A Mathematical Theory of Economic Growth: The Public Choice Growth Model, MPRA 2020, Paper No 99940. Available online: https:/ / mpra.ub.unimuenchen.de/99940/1/MPRA_paper_99940.pdf (accessed on 15 March 2021).

47. Anh, N.N.; Tran-Nam, B. Corruption and economic growth, with a focus on Vietnam. Contemp. Crises 2016, 65, 307-324. [CrossRef]

48. Montes, G.C.; Luna, P.H.L. Fiscal transparency, legal system and perception of the control on corruption: Empirical evidence from panel data. Empir. Econ. 2021, 60, 2005-2037. [CrossRef]

49. Heckelman, J.C.; Powell, B. Corruption and the Institutional Environment for Growth. Comp. Econ. Stud. 2010, 52, 351-378. [CrossRef]

50. Saha, S.; Gounder, R. Corruption and economic development nexus: Variations across income levels in a non-linear framework. Econ. Model. 2013, 31, 70-79. [CrossRef]

51. Peev, E.; Mueller, D.C. Democracy, Economic Freedom and Growth in Transition Economies. Kyklos 2012, 65, 371-407. [CrossRef]

52. Groșanu, A.; Boţa-Avram, C.; Răchişan, P.R.; Vesselinov, R.; Tiron-Tudor, A. The influence of country-level governance on business environment and entrepreneurship: A global perspective. Amfiteatru Econ. 2014, 17, 62-78. Available online: https: / / www.econstor.eu/handle/10419/168902 (accessed on 1 March 2021).

53. European Commission. European Semester Country Report-Romania. Commission Staff Working Document. Country Report Romania 2019 Including an In-Depth Review on the Prevention and Correction of Macroeconomic Imbalances 2019. Available online: https:/ / ec.europa.eu/info/sites/info/files/file_import/2019-european-semester-country-report-romania_en.pdf (accessed on 16 April 2021).

54. Gil-García, J.R.; Puron-Cid, G. Using panel data techniques for social science research: An illustrative case and some guidelines. CIENCIA ergo-sum. Rev. Cientifica Multidiscip. Prospect. 2014, 21, 203-216. Available online: https://www.redalyc.org/pdf/104/ 10432355004.pdf (accessed on 2 March 2021).

55. Torres-Reyna, O. Panel Data Analysis Fixed and Random Effects Using Stata (v. 4.2). Data E Statistical Services; Princeton University: Princeton, NJ, USA, 2007; p. 112. Available online: https://www.princeton.edu/ $\{$ \}otorres/Regression101.pdf (accessed on 30 March 2021).

56. Blackwell, J.L. Estimation and Testing of Fixed-effect Panel-data Systems. Stata J. Promot. Commun. Stat. Stata 2005, 5, 202-207. [CrossRef]

57. Akca, H.; Ata, A.Y.; Karaca, C. Inflation and corruption relationship: Evidence from panel data in developed and developing countries. Int. J. Econ. Financ. Issues 2012, 2, 281-295. Available online: https://www.researchgate.net/profile/DrCoskunKaraca/publication/241756315_Inflation_and_Corruption_Relationship_Evidence_from_Panel_Data_in_Developed_ and_Developing_Countries/links/569e5ce308ae192a92a4a5f0/Inflation-and-Corruption-Relationship-Evidence-from-PanelData-in-Developed-and-Developing-Countries.pdf (accessed on 18 March 2021).

58. Blagojevic, S.; Damijan, J.P. Impact of Private Incidence of Corruption and Firm Ownership on Performance of Firms in Central and Eastern Europe, LICOS Discussion Paper 2012. Available online: https:/ /www.econstor.eu/bitstream/10419/74836/1/dp310.pdf (accessed on 1 June 2021).

59. Bakowski, P.; Varonova, S. Corruption in the European Union: Prevalence of Corruption, and Anti-Corruption Efforts in Selected EU Member States; EPRS I European Parliamentary Research Service: Luxembourg, 2017; p. 10. Available online: https://www. europarl.europa.eu/RegData/etudes/STUD/2017/608687/EPRS_STU(2017)608687_EN.pdf (accessed on 1 June 2021).

60. Van Der Hoek, M.P. Enlarging the European Union: Taxation and Corruption in the New Member States. In Taxation and Public Finance in Transition and Developing Economies; Springer Science and Business Media LLC: Berlin, Germany, 2008; pp. 11-23.

61. Tromme, M.; Volintiru, C. Corruption Risks at the Local Level in the EU and EU Periphery Countries; OECD Global Anti-corruption \& Integrity Forum: Paris, France, 2018. Available online: https:/ /www.oecd.org/corruption/integrity-forum/academic-papers/ Tromme.pdf (accessed on 1 June 2021).

62. Ropret, M.; Aristovnik, A.; Kovač, P. A Content analysis of the rule of law within public governance models: Old vs. new EU member states. Network of Institutes and Schools of Public Administration in Central and Eastern Europe. the NISPAcee. J. Public Adm. Policy 2018, 11, 129-152. Available online: https:/ / www.proquest.com/openview/b4d75e0d0eb553b5c0fc18bc3a212067/1? pq-origsite $=$ gscholar\&cbl=2026589 (accessed on 1 June 2021).

63. Libman, A. Democracy, size of bureaucracy, and economic growth: Evidence from Russian regions. Empir. Econ. 2012, 43, 1321-1352. [CrossRef]

64. Ostrom, E.; Ostrom, V. The Quest for Meaning in Public Choice. Am. J. Econ. Sociol. 2004, 63, 105-147. [CrossRef] 